\title{
PENANAMAN NILAI-NILAI KARAKTER TERHADAP ANAK SEBAGAI PENDIDIKAN DASAR BERDASARKAN KISAH LUQMAN DALAM AL-QUR'AN
}

\author{
Mutaqin Al Zam Zami \\ UIN Sunan Kalijaga Yogyakarta \\ muttaqinalzamzami86@gmail.com
}

\begin{abstract}
Educators and parents should teach according to the aims of learning priorities. The priority of Islamic education is not only concerned with cognitive aspects but also the affective aspect which becomes more important. The story of Luqman in the Quran can be used as an example of how to shape character values. By knowing the right method according to Lukman's story, teaching is expected to get better results. There are three methods used by Luqman in shaping character values: 1) Giving Mauizah (kindness, spaciousness, tenderness and eliminating arrogance; 2) Teaching with Compassion, such as Luqman's gentle calling to his child (yaa bunayya); 3) Gradual Teaching (aqeedah education, shariah education, moral education).
\end{abstract}

Keywords: Character, Basic Education, Qur'an

\section{Pendahuluan}

Pembentukan karakter merupakan sesuatu yang sangat penting dalam kehidupan. Karakter adalah mutiara hidup yang membedakan manusia dengan binatang. Pembentukan karakter dipengaruhi oleh banyak hal, baik dari internal maupun eksternal, akan tetapi faktor utama yang paling berpengaruh dalam pembentukan karakter ialah keluarga dan harus dilakukan sejak dini.

Islam selain mengatur hubungan dengan Allah (habl min Allah) juga memberi petunjuk tentang interaksi sesama manusia (habl min al-nas). Berkaitan dengan habl min al-nas seseorang berdampak pada interaksinya 
dengan orang lain. Seseorang yang memiliki individu yang baik tentu akan membawa kemanfaatan bagi segala yang ada di sekelilingnya. Sebaliknya, individu dengan karakter buruk akan memberi efek buruk serta berimplikasi pada rusaknya hubungan sosial.

Al-Qur'an sebagai kitab pedoman memiliki perhatian besar terhadap pembentukan karakter. Uniknya, al-Qur'an memiliki berbagai bentuk penuturan dalam menyampaikan pesan-pesannya. Diantara bentuk penuturan tersebut ialah dengan kisah-kisah umat terdahulu.

Berkenaan dengan pembentukan karakter, al-Qur'an mengisahkan Luqman yang berusaha menanamkan nilai-nilai karakter pada anaknya. Maka, dirasa perlu adanya kajian mengenai metode yang digunakan oleh Luqman dalam pembentukan nilai-nilai karakter agar dapat diaplikasikan dalam kehidupan masa kini.

\section{Metode Penelitian}

\section{Jenis dan Pendekatan Penelitian}

Penelitian ini menggunakan jenis penelitian pustaka (library research), yaitu penelitian yang menggunakan data dan informasi dengan bantuan berbagai macam material seperti buku-buku, jurnal, naskah-naskah serta dokumen-dokumen lain. Sifat penelitian ini adalah kualitatif, yaitu penelitian berasas pada kualitas dari data-data yang telah diuraikan dan dianalisis secara sistematis.

Adapun penelitian ini menggunakan pendekatan kontekstual, yaitu mendudukkan keterkaitan antara yang sentral dengan perifer sebagai terapannya. Sesuatu yang sentral adalah studi tentang ayatayat Qur'aniyah, sedangkah yang perifer adalah studi tentang ayatayat kauniyah. Dengan pendekatan kontekstual ini diharapkan metode yang digunakan Luqman dalam pembentukan karakter tidak hanya dapat dimengerti dan dipahami. Akan tetapi, metode itu dapat diterapkan dalam kehidupan nyata sehingga dapat digunakan oleh pendidik, terutama orangtua, dalam membentuk karakter yang sesuai dengan nilai-nilai Islam.

\section{Sumber Data}


Dalam penulisan ini, penulis melakukan pencarian dari berbagai sumber-sumber data yang mempunnyai relevansi dengan tema penelitian ini. Adapun data yang digunakan berasal dari sumber data primer dan skunder. Sumber data primernya adalah surat Luqman ayat 12-19 dan penafsiran-penafsiran ulama terhadapnya. Sementara sumber data skunder, yaitu kitab-kitab, buku-buku, artikel serta literatur-literatur lainnya yang terkait dengan tema.

\section{Teknik Pengumpulan Data}

Teknik yang digunakan adalah pengumpulan data literer, yaitu bahan-bahan pustaka yang koheren dengan objek pembahasan yang dimaksud. Data yang data dalam kepustakaan tersebut dikumpulkan dan diolah dengan cara: 1) editing, yaitu pemeriksaan kembali yang diperoleh, terutama dari segi kelengkapan serta kejelasan makna antara satu dengan yang lain; 2) organizing, yaitu mengorganisir datadata yang diperoleh dengan kerangka yang sudah dibuat;3) Penemuan hasil penelitian, yaitu melakukan analisis lanjutan terhadap hasil pengorganisasian data dengan menggunakan kaidah-kaidah, teori dan metode yang telah ditentukan sehingga diperoleh kesimpulan tertentu yang merupakan hasil jawaban dari rumusan masalah.

\section{Analisis Data}

Dalam menganalisa data, penulis menggunakan analisis isi (content analysis) yaitu suatu metode tafsir yang digunakan oleh para mufasir dalam menjelaskan kandungan al-Qur'an dari berbagai seginya. Analisis ini dimulai dengan menyebutkan ayat-ayat yang akan ditafsirkan lalu menjelaskan makna yang telah dikemukakan oleh mufasir terdahulu. Kemudian ayat-ayat yang telah ditafsirkan itu dideskripsikan dan dianalisa secara jelas, sehingga dapat diambil kesimpulan.

\section{Konsep Karakter}

Secara etimologis, kata karakter (Inggris: Character) berasal dari bahasa Yunani, eharassein yang berarti "to engrave" (Ryan and Bohlin, 1999: 5). Kata "to engrave" itu sendiri dapat diterjemahkan menjadi 
mengukir, melukis, memahatkan, atau menggoreskan (Echols dan Shadily, 1995: 214). Dalam bahasa indonesia "karakter" diartikan sebagai tabiat, sifat-sifat kejiwaan, akhlak, atau budi pekerti yang membedakan seseorang dengan yang lain.

Secara terminologis D. Yahya Khan (2010: 1) menyatakan bahwa karakter adalah sikap pribadi yang stabil hasil proses konsolidasi secara progresif dan dinamis, integrasi antara pernyataan dan tindakan. Dengan demikian, dapat disimpulkan bahwa pendidikan karakter adalah usaha membantu mengembangkan potensi manusia agar terbentuk akhlak, watak, dan kepribadian sebagai manusia.

Menurut Kamus Besar Bahasa Indonesia (2008) karakter merupakan sifat-sifat kejiwaan, akhlak atau budi pekerti yang membedakan seseorang dengan yang lain. Dengan demikian karakter adalah nilainilai yang unik-baik yang terpatri dalam diri dan terjewantahkan dalam perilaku (Kementrian Pendidikan Nasional, 2010). Muchlas Samani \& Hariyanto mengutip dari Warsono dkk. (2010) menyatakan: "karakter dimaknai sebagai cara berpikir dan berperilaku yang khas tiap individu untuk hidup dan bekerja sama, baik dalam lingkup keluarga, masyarakat, bangsa, dan negara. Individu yang berkarakter baik adalah individu yang dapat membuat keputusan dan siap mempertanggungjawabkan setiap akibat dari keputusannya".

\section{Analisis Metode yang Digunakan Luqman dalam Pembentukan Nilai-nilai Karakter}

\section{Pemberian Mauizah}

Secara terminologi kata mauizah berasal dari bahasa Arab wa'azha-wa'zhan-wa'izhatan (وعظ- وعظا- وعظة). Kata ini diartikan menasehati. Derivasinya menjadi al-'izhah-al-wa'zhah-al-mauizah diartikan sebagai kata-kata nasehat. Para ahli ilmu juga mengartikan al-mauizah sebagai al-tadzkir (peringatan) untuk kebaikan, kelapangan hati, kelembutan hati dan menghilangkan kerasnya hati. Mauizah dapat melembutkan hati yang keras, meneteskan air mata yang membeku dan memperbaiki perbuatan yang rusak.

Dalam Tanwir al-Miqbash dijelaskan bahwa lafadh (يعظه) berarti nasihat, adapun bentuk nasihatnya yakni dengan melarang Amr 
Ma'ruf Nahi Munkar (perintah kebajikan dan larangan berbuat buruk).

Kata ini terdapat dalam banyak ayat di dalam al-Qur'an dengan berbagai derivasinya. Berdasarkan informasi dari kitab al-Mu'jam alMufahras li Alfadz al-Qur'an. Diantara metode yang digunakan Luqman dalam pembentukan karakter ialah dengan mauizah. Hal ini tergambar dalam firman Allah SWT. pada ayat berikut:

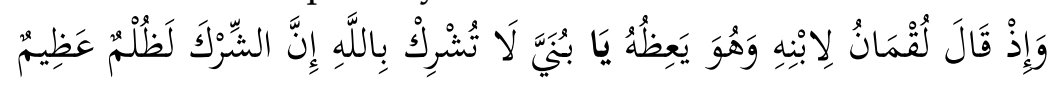

“Dan (ingatlah) ketika Lukman berkata kepada anaknya, ketika dia memberi pelajaran kepadanya, "Wahai anakku! Janganlah engkau mempersekutukan Allah, sesungguhnya mempersekutukan (Allah) adalah benar-benar kezaliman yang besar."

\section{Pengajaran dengan Kasih Sayang}

Pembentukan karakter yang dilakukan Luqman juga menggunakan metode pengajaran dengan kasih sayang. Hal ini dapat terlihat pada cara Luqman memanggil anaknya dengan panggilan kesayangan, yaitu yaa bunayya (يبني). Penggilan ini menggambarkan kemungilan. Asalnya adalah ibnii (ابني) dari kata ibn (بني) yang berarti anak laki-laki. Panggilan inilah yang mengisyaratkan adanya kasih saying, maka dapat dipahami bahwa dalam pembentukan nilai-nilai karakter hendaknya didasari oleh rasa kasih sayang.

Kata (يابني) menurut tafsir Jalalain mempunyai bentuk tashghir yang menunjukkan arti kesayangan. Secara bahasa lafadh (بُنيْيَ) berasal

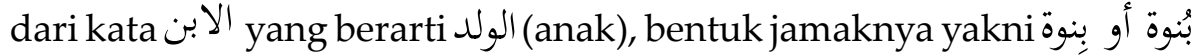

Ada beragam term yang digunakan al-Qur'an yang bermakna anak dengan berbagai derivasinya seperti zurriyah, ibn, walad, athfal, shabiy, aqrab, asbath, ghulam, thifl, nasl, rabaib serta ad'iya. Akan tetapi setiap kata tersebut dimaknai anak sesuai konteksnya masing-masing.

\section{Pengajaran Bertahap}

Materi yang diajarkan Luqman dapat diklasifikasikan ke dalam tiga pokok pendidikan, yaitu pendidikan aqidah, pendidikan syariah dan pendidikan akhlak. Dari sinilah disimpulkan bahwa di antara 


\section{eL-Tarbauj Mutaina Azamzami}

metode pembentukan karakter yang dilakukan oleh Luqman ialah pengajaran secara bertahap. Berikut uraian tahapan tersebut:

\section{Pendidikan Aqidah}

Di antara pendidikan syari'ah yang dijelaskan dalam surat Luqman ayat 12-19 ialah sebagai berikut:

a) Larangan menyekutukan Allah, Karena menyekutukan Allah merupakan dosa serta kedhaliman yang paling besar.

b) Meyakini adanya tempat kembali.

\section{Pendidikan Syari'ah}

Di antara pendidikan syari'ah yang dijelaskan dalam surat Luqman ayat 12-19 ialah sebagai berikut:

a) Perintah mendirikan Shalat.

b) Perintah Amar Ma'ruf Nahi Munkar.

c) Pendidikan Akhlak.

Di antara pendidikan syari'ah yang dijelaskan dalam surat Luqman ayat 12-19 ialah sebagai berikut:

a) Mensyukuri nikmat Allah SWT.

b) Berbuat baik kepada kedua orang tua.

c) Larangan berbuat sombong.

d) Perinntah berbicara halus dan sopan.

Kontekstualisasi Metode yang Digunakan Luqman di Era Kontemporer

Metode yang digunakan Luqman dalam pembentukan nilai-nilai karakter, dalam hal ini kami mencantumkan tiga metode, yaitu 1) pemberian mauizah, 2) pengajaran dengan kasih sayang, 3) pengajaran bertahap. Ketiga metode tersebut jika dikontekstualisasikan di era kontemporer ini tentu sangat relevan.

Metode pemberian mauizah jika diterapkan di era kontemporer sekarang tentu sangat dibutuhkan dalam pembentukan karakter anak, karena metode ini pada intinya orangtua atau guru mengajak anak maupun muridnya untuk berdialog dalam memberikan nasehat yang dapat menumbuhkan karakter anak yang baik. 
Metode kedua, yaitu pengajaran dengan kasih sayang, setiap anak jika diajarkan dengan kelembutan dan kasih sayang baik dari orangtua maupun guru tentu memiliki kesan yang baik bagi psikologi anak. Anak akan lebih tersentuh hati dan pikirannya untuk lebih cepat menangkap apa yang telah disampaikan orangtua maupun gurunya.

Metode terakhir ialah pengajaran bertahap, merupakan metode yang sebenarnya tidak akan mungkin bisa kita lepaskan dalam pembentukan karakter anak. Karena kemampuan anak dalam menangkap suatu pengajaran sangat berpengaruh dengan usianya, sehingga orangtua dan guru sangat berperan aktif dalam meninjau pertumbuhan anak-anaknya dan mengajarkan apa yang semestinya layak untuk dia peroleh.

\section{Kesimpulan}

Berdasarkan penelitian yang telah dilakukan maka ditemukan beberapa kesimpulan sebagai berikut:

Berdasarkan beberapa penafsiran terhadap kisah Luqman maka ada beberapa pengajaran yang ditemukan; yaitu: jangan mempersekutukan Allah SWT; berbuat baik kepada orang tua; yakni dengan mematuhi dan berbakti kepada keduanya; laksanakan sholat; menyeru kebaikan kepada orang lain; mencegah keburukan; bersabar terhadap musibah; jangan bersikap sombong; bersikaplah sederhana. Kemudian analisis terhadap sikap Luqman maka ditemukan tiga metode yang dilakukannya dalam pembentukan nilai-nilai karakter, yaitu; pemberian mau'izah, pengajaran dengan kasih sayang dan pengajaran bertahap. Apabila dikontekstualisasikan metode yang digunakan Luqman dalam pembentukan nilai-nilai karakter, yaitu; 1) pemberian mauizah; 2) pengajaran dengan kasih sayang; 3) pengajaran bertahap tentu sangat relevan, karena konteks sekarang anak sangat membutuhkan ketiga metode yang akan diterapkan orangtua dan guru dalam pembentukan karakter baik.

\section{Daftar Pustaka}

Al-Jarjani, Ali bin Muhammad 1983. Kitab al-Ta'rifat. Beirut: Dar alKutub al-Ilmiyah. 


\section{eL-Tarbawj Mutain A I Zam Zami}

Arikunto, Suharsimi. Prosedur Penelitian: Suatu Pendekatan Praktek. Jakarta: Rineka Cipta.

As-suyuti, Jalaluddin Jalaludin al-Mahalli, Tafsir Jalalain. Kairo: Dar al-Hadits.

Helmawati. 2014. Pendidikan Keluarga "Teoritis dan Praktis". Bandung: Remaja Rosdakarya.

Kartini. 1996. Pengantar Metodologi Riset Sosial. Banadung: Mandar Maju.

Katsir, Abu al-Fida' Ismail bin 'Umar bin. Tafsir al-Qur'an al-Adhim. Beirut: Dar al-Haram.

Mandzur, Ibn. Lisan al-Arab. Mesir: Dar al-Ma'arif.

Muhadzir, Noeng. 1996. Metode Penelitian Kualitatif. Yogyakarta: Rake Sarasin.

Munawwir, Ahmad Warson. 1997. Al-Munawwir: Kamus ArabIndonesia Terlengkap. Surabaya: Pustaka Progressif.

Rofiqoh, Siti Ulwatul. 2015. “Nilai-nilai Pendidikan Karakter dalam Kisah Luqman al-Hakim (Telaah Tafsir Surat Luqman Ayat 1219)". Yogyakarta: Skripsi Fakultas Ilmu Tarbiyah dan Keguruan UIN Sunan Kalijaga.

Samani, Muchlas \& Hariyanto. 2013. Pendidikan Karakter. Bandung: Remaja Rosdakarya.

Suyadi. 2013. Strategi Pembelajaran Pendidikan Karakter. Bandung: Remaja Rosdakarya.

Utsman bin Sa'id al-Dani. 2007. Al-Farq bain al-Dhad wa al-Dzha fii Kitab Allah Azza wa Jalla wa fii al-Masyhur min al-Kalam. Damaskus: Dar al-Basyair.

Zabadi, Fairuz. Tanwir al-Miqbash min Tafsir ibn Abbas. Beirut: Dar al-Kutub. 